\title{
CREDIBILITY OF INFORMATION SOURCES USED BY ARTISANAL FISHERS IN SELECTED COASTAL STATES OF NIGERIA
}

\author{
Gbarabe Roland ${ }^{1}$, Ngodigha Sabina Alatari ${ }^{2 *}$, Adesope M.O ${ }^{3}$, Mordiwa Sinah ${ }^{4}$ \\ ${ }^{1 \& 4}$ Department of Agricultural Economics and Extension, North West University, South Africa; \\ ${ }^{2 *}$ Department of Agricultural Education, Isaac Jasper Boro College of Education, Bayelsa State, Nigeria; \\ ${ }^{3}$ Department of Agricultural Economics and Extension, University of Port-Harcourt, Nigeria; \\ *Correspondence author Ngodigha Sabina Alatari, e-mail: alatari3004@gmail.com;
}

Received March 2019; Accepted April 2019; Published June 2019;

DOI: https://doi.org/10.31407/ijees9217

UOI license: http://u-o-i.org/1.01/ijees/61737367

\begin{abstract}
A study on credibility of information sources used by artisanal fishers in selected coastal states of Nigeria was carried out between January 2018 and December 2018. The study focused on Bayelsa, Rivers and Akwa Ibom states, Nigeria in West Africa. Data was obtained from primary sources using questionnaire. Descriptive and inferential statistical analysis was employed. The result indicates that majority of the artisanal fishers were male (79.90\%) and $43 \%$ of the fishers falls within the age bracket of between $41-50$ years. About $5.2 \%$ have been engaged in fishing activities for the past 15 years and above, while $88 \%$ of the artisanal fishers had one form of education or the other. Majority of artisanal fishers (55\%) earn monthly income of between $\$ 11,000-\$ 50,000$ ( $\$ 30$ - \$130). The low income earned by fishers have negative effect on their livelihood. The most credible sources of information was: Fishers groups (75\%), credit agencies $(66.5 \%)$, output buyers $(55.2 \%)$ and cell phones $(50.9 \%)$. From the study, it is obvious that artisanal fishers need credible information in nearly all the coastal areas of Nigeria to improve the fishing industry which could eventually improve their livelihood.
\end{abstract}

Key word: accessibility, artisanal fishers, credibility, dissemination, fishing, information source. 